University of Nebraska - Lincoln

DigitalCommons@University of Nebraska - Lincoln

\title{
2,3,7,8-Tetrachlorodibenzo-p-dioxin induces apoptotic cell death and cytochrome P4501A expression in developing Fundulus heteroclitus embryos
}

\author{
Barbara Holland Toomey \\ Duke University, btoomey@dellnet.com \\ Susan Bello \\ Woods Hole Oceanographic Institute \\ Mark E. Hahn \\ Woods Hole Oceanographic Institute, mhahn@whoi.edu \\ Susannah Cantrell \\ U.S. Geological Survey \\ Peggy Wright \\ U.S. Geological Survey \\ See next page for additional authors \\ Follow this and additional works at: https://digitalcommons.unl.edu/usgsstaffpub \\ Part of the Geology Commons, Oceanography and Atmospheric Sciences and Meteorology Commons, \\ Other Earth Sciences Commons, and the Other Environmental Sciences Commons
}

Toomey, Barbara Holland; Bello, Susan; Hahn, Mark E.; Cantrell, Susannah; Wright, Peggy; Tillitt, Donald E.; and Di Giulio, Richard T., "2,3,7,8-Tetrachlorodibenzo-p-dioxin induces apoptotic cell death and cytochrome P4501A expression in developing Fundulus heteroclitus embryos" (2001). USGS Staff -- Published Research. 576.

https://digitalcommons.unl.edu/usgsstaffpub/576

This Article is brought to you for free and open access by the US Geological Survey at DigitalCommons@University of Nebraska - Lincoln. It has been accepted for inclusion in USGS Staff -- Published Research by an authorized administrator of DigitalCommons@University of Nebraska - Lincoln. 


\section{Authors}

Barbara Holland Toomey, Susan Bello, Mark E. Hahn, Susannah Cantrell, Peggy Wright, Donald E. Tillitt, and Richard T. Di Giulio 


\title{
2,3,7,8-Tetrachlorodibenzo- $p$-dioxin induces apoptotic cell death and cytochrome P4501A expression in developing Fundulus heteroclitus embryos
}

\author{
Barbara Holland Toomey ${ }^{\mathrm{a}, *}$, Susan Bello ${ }^{\mathrm{b}}$, Mark E. Hahn ${ }^{\mathrm{b}}$, \\ Susannah Cantrell ${ }^{\mathrm{c}, \mathrm{d}}$, Peggy Wright ${ }^{\mathrm{c}, \mathrm{e}}$, Donald E. Tillitt ${ }^{\mathrm{c}}$, \\ Richard T. Di Giulio a,1 \\ a Nicholas School of the Environment, Duke University, Durham, NC 27709, USA \\ ${ }^{\mathrm{b}}$ Woods Hole Oceanographic Institute, Woods Hole, MA 02543, USA \\ ' Columbia Environmental Research Center, USGS, Columbia, MO 65201, USA \\ d Department of Biochemistry, University of Missouri, Columbia, MO 65202, USA \\ e Department of Fisheries and Wildlife Sciences, University of Missouri, Columbia, MO 65202, USA
}

Received 25 February 2000; received in revised form 1 August 2000; accepted 8 August 2000

\begin{abstract}
Fundulus heteroclitus embryos were exposed to 2,3,7,8-tetrachlorodibenzo-p-dioxin (TCDD) during early development using nanoinjection or water bath exposure. TCDD caused developmental abnormalities that included hemorrhaging, loss of vascular integrity, edema, stunted development and death. The $\mathrm{LC}_{50}$ and $\mathrm{LD}_{50}$ of TCDD for Fundulus embryos were $\sim 19.7 \pm 9.5 \mathrm{pg} \mathrm{TCDD} / \mu \mathrm{l}$ (water bath) and $0.25 \pm 0.09 \mathrm{ng} \mathrm{TCDD} / \mathrm{g}$ embryo (nanoinjection). To identify a possible cause for these developmental abnormalities we analyzed the effects of TCDD on apoptotic cell death and cytochrome P4501A (CYP1A) expression in the embryos. TCDD exposure increased apoptotic cell death in several tissues including brain, eye, gill, kidney, tail, intestine, heart, and vascular tissue. CYP1A expression was also increased in the TCDD-exposed embryos predominantly in liver, kidney, gill, heart, intestine, and in vascular tissues throughout the embryo. There was co-occurrence of TCDD-induced apoptosis and CYP1A expression in some, but not all, cell types. In addition the dose response relationships for apoptosis and mortality were similar, while CYP1A expression appeared more sensitive to TCDD induction. (C) 2001 Elsevier Science B.V. All rights reserved.
\end{abstract}

Keywords: Apoptosis; Cell death; Cytochrome P450; Embryo; Fundulus

* Corresponding author. Present address: 411 Millbrook Road, Middletown, CT 06457-5543, USA. Tel.: + 1-860-3449634.

E-mail addresses: btoomey@dellnet.com (B.H. Toomey), richd@acpub.duke.edu (R.T. Di Giulio).

${ }^{1}$ Also corresponding author. Tel.: + 1-919-6138024; fax: + 1-919-6848741.

0166-445X/01/\$ - see front matter (C) 2001 Elsevier Science B.V. All rights reserved.

PII: S0166-445X(00)00161-2

This article is a U.S. government work, and is not subject to copyright in the United States. 


\section{Introduction}

Certain halogenated aromatic hydrocarbons including 2,3,7,8 - tetrachlorodibenzo - $p$ - dioxin (TCDD) are extremely toxic to early life stages of a variety of fish, avian, and mammalian species (Peterson et al., 1993). TCDD is a teratogen and developmental toxicant in many species but is especially potent at inducing hydronephrosis and cleft palate in mouse embryos (Birnbaum, 1994). TCDD can also affect the endocrine and reproductive systems (Peterson et al., 1993; Birnbaum, 1994; Heimler et al., 1998), as well as the development of other organ systems (Sakamoto et al., 1995; Henshel, 1998; MacLusky et al., 1998).

In the laboratory TCDD has been shown to induce abnormal development similar to blue sac disease and increase cell death (especially in vascular endothelium) in medaka (Oryzias latipes) embryos (Cantrell et al., 1996, 1998). Spitsbergen et al. (1991) also found the developing vascular tissue is a sensitive target of TCDD in fish embryos and fry. Furthermore, TCDD-induced vascular cell death was correlated with embryotoxicity and co-localized with CYP1A expression in the vasculature of medaka, and sublethal doses of TCDD increased cell death in digestive and gill tissues (Cantrell et al., 1998). In TCDD-exposed trout embryos, endothelial CYP1A expression and sac fry mortality occurred with similar dose-response relationships (Guiney, et al., 1997).

TCDD acts on the cell through the aryl hydrocarbon receptor (AhR) leading to induction of CYP1A activity and altered expression of other genes encoding detoxification enzymes such as CYP1A2, CYP1B1, and NAD(P)H:Quinone oxidoreductase (Nebert et al., 1990, 2000; reviewed in Whitlock et al., 1997). Stimulation of CYP1A and other enzymes can lead to cellular and physiological signs of oxidative stress (Stegeman and Hahn, 1994; Yao et al., 1995) and may contribute to cellular damage and cell death (Kurl et al., 1993; Sakamoto et al., 1995).

Programmed cell death is an important process of normal development which can be easily altered by extraneous or toxic signals to cells. It appears that many teratogens, including TCDD, can act by altering apoptosis resulting in developmental abnormalities (Sulik et al., 1988; Sakamoto, et al., 1995). In addition, TCDD-induced teratogenesis in mice, and presumably other mammals, is AhR-dependent (Mimura, et al., 1997; Peters et al., 1999).

Cytochrome P450 enzyme systems are present and active at a low level during embryonic development in Fundulus (Binder and Stegeman, 1984). Cytochrome P450-dependent aryl hydrocarbon hydroxylase $(\mathrm{AHH})$ enzyme activity is inducible by halogenated hydrocarbons before hatching, but basal microsomal AHH activity and its inducibility by PCBs increase within $24 \mathrm{~h}$ of hatching (Binder and Stegeman, 1980, 1984; Binder et al., 1985). Recently, a Fundulus CYP1A cDNA has been cloned (Morrison et al., 1998). Although the expression of CYP1A and other CYPs in adult and embryonic Fundulus has been described previously, immunohistochemical localization of constitutive or induced CYP1A expression in developing Fundulus embryos has not been reported.

The mummichog Fundulus heteroclitus, a common and widespread marine/estuarine fish along the Atlantic coast of the United States, is used as a model species for both ecological and toxicological studies. Fundulus is emerging as an especially valuable model organism for developmental toxicology. The reproductive and developmental biology of Fundulus is well known (Armstrong and Child, 1965; Selman and Wallace, 1986), and this species possesses many of the same attributes that have motivated research on development in zebrafish (Detrich et al., 1999). In addition, Fundulus has been important in studies of evolutionary adaptation to changing environmental conditions (Powers and Schulte, 1998). Several wild populations of Fundulus have developed resistance to toxicants including TCDD (reviewed in Hahn, 1998). An understanding of the mechanism of TCDD embryotoxicity in Fundulus will help us to determine mechanisms of resistance in these populations. Although TCDD embryotoxicity has been well characterized in several freshwater fish species (Spitsbergen et al., 1991; Henry et al. 1997; Elonen et al., 1998), there is little information on the sensitivity of marine fish to TCDD. Therefore, we determined the effects of TCDD on 
development, cell death, and CYP1A expression in the embryos of $F$. heteroclitus in order to characterize the response to TCDD in this important marine species.

\section{Methods}

\subsection{Chemicals}

Instant Ocean, Tetramin ${ }^{\circledR}$, and brine shrimp flakes were from Pet Warehouse (Dayton, $\mathrm{OH}$ ). AEC (3-amino-9-ethylcarbazole) kit, BSA, paraformaldehyde, salts, HEPES, hematoxylin, triolein, and peroxidase were from Sigma (St. Louis, MO). Tdt enzyme was from Promega (Madison, WI), and 12-FL-dUTP and digoxygenin-dUTP were from Boehringer Mannheim (Indianapolis, IN). Secondary antibodies were from BioRad Labs (Richmond, CA). Paraffin was from Fisher (Suwanee, GA). TCDD was a gift from Dow Chemical Co., and the purity ( $>98 \%$ ) and concentrations were confirmed by gas chromatography/ mass spectrometry.

\subsection{Fish}

Adult Fundulus were collected from tidal streams near Beaufort, $\mathrm{NC}$ and were maintained in aquaria at Duke University using American Association for the Accreditation of Laboratory Animal Care (AAALAC) approved facilities and protocols. The aquaria were filled with dechlorinated water containing sufficient Instant Ocean to produce artificial sea water (ASW) with a salinity of $(18-20 \mathrm{ppt})$; the water was changed one to two times per week. The fish were fed Tetramin ${ }^{\circledR}$ flake food twice and brine shrimp flakes once daily to maintain breeding condition. The water temperature $\left(23^{\circ} \mathrm{C}\right)$ and photoperiod (14:10, light:dark) were also set to induce breeding condition.

Eggs and milt of Fundulus were collected manually according to Armstrong and Child (1965). Eggs were fertilized by mixing with sperm and after $20 \mathrm{~min}$ were rinsed three times with ASW. Fertilized eggs were allowed to develop for several hours, and only embryos that appeared normal were used for TCDD exposures.

\subsection{Nanoinjection}

One group of embryos (20 embryos per dose) at stage 16 (Armstrong and Child, 1965) was exposed to TCDD via nanoinjection according to Walker et al. (1996) and Wilson and Tillitt (1996). TCDD was dissolved in triolein and injected into the yolk of each embryo at the following concentrations: 0 (triolein), 0.025, 0.05, 0.5, 5 and $20 \mathrm{ng} / \mathrm{g}$ embryo. The embryos were then allowed to develop in petri dishes with filter paper soaked in ASW. Their development was monitored daily, and any abnormalities were noted. These embryos were used to confirm the embryotoxicity results of the water bath exposed embryos and to obtain a number for the $\mathrm{LD}_{50}$. We did not have enough injected embryos to also do TUNEL and CYP1A assays.

\subsection{Water bath exposure}

A second group of embryos (40 embryos per dose) at stage 16 was exposed to TCDD in a water bath. Each embryo was placed in $20 \mu \mathrm{l}$ of ASW containing $2 \mu \mathrm{l}$ of TCDD solution in iso-octane at the following concentrations: $0,0+2 \mu 1$ triolein, $3.1,6.2,12.5,25,50,100$ or $500 \mathrm{pg} / \mu 1$. Embryos were removed from the TCDD solutions after $2 \mathrm{~h}$ and allowed to develop on filter paper soaked in ASW.

Embryos developed at $22^{\circ} \mathrm{C}$, and morphology was monitored daily. Three criteria: (1) presence of a beating heart; (2) intact pericardial sac; and (3) circulating blood were used to assess embryo viability. At various stages during development [early (stage 28-29); mid (stage 31-32); late (stage 35-36) (Armstrong and Child, 1965)] six embryos from each dose of TCDD (water bath exposure) were collected and fixed for analysis of cell death and CYP1A expression.

\subsection{Embryo preparation}

Embryos (water bath exposed) were fixed in 4\% paraformaldehyde in HEPES buffer containing $350 \mathrm{mM} \mathrm{NaCl}, 150 \mathrm{mM}$ HEPES, and $10 \mathrm{mM}$ $\mathrm{CaCl}_{2}$ (pH 7.2) overnight at $4^{\circ} \mathrm{C}$. After $1 \mathrm{~h}$, a hole was made in the chorion surrounding the embryo to ensure penetration of the fixative. Embryos 
were rinsed for $1 \mathrm{~h}$ in phosphate buffered saline (PBS) and dehydrated in 50 and $70 \%$ ethanol for $1 \mathrm{~h}$ each. The chorions were removed, and the embryos stored in $70 \%$ ethanol at $4^{\circ} \mathrm{C}$.

Embryos were further dehydrated in $95 \%$ ethanol and two changes of $100 \%$ ethanol before clearing in two changes of xylenes and infiltration with paraffin at $56^{\circ} \mathrm{C}$. Embryos were embedded in paraffin, cut into $10 \mu \mathrm{m}$ thick sections, and mounted on superfrost plus slides (Fisher).

\subsection{TUNEL assay}

Cell death was analyzed with an in situ end-labeling assay that uses terminal deoxynucleotidyl transferase (TdT; TUNEL assay; Gavrieli et al., 1992). TdT catalyzes the addition of a labeled nucleotide to the 3' $\mathrm{OH}$ ends of DNA. Greater 3' $\mathrm{OH}$ labeling indicates increased DNA fragmentation, a distinguishing characteristic of apoptosis. This assay was carried out on sections of Fundulus embryos using a protocol similar to Piqueras et al. (1996) using both fluorescent and non-flourescent labeling techniques. A nonfluorescent method was used to confirm results with the fluorescent method in which the embryos had some background autofluorescence. Embryo sections were labeled with either fluorescein-dUTP or digoxygenin-dUTP with a secondary antibody conjugated to horseradish peroxidase (HRP). Thus apoptotic cells were detected with epifluorescence or light microscopy depending on the label used. Briefly, embryo sections were deparaffinized, rehydrated, and prepared for the TUNEL assay [10 min in $0.01 \mathrm{mg} / \mathrm{ml}$ proteinase $\mathrm{K}$ at $37^{\circ} \mathrm{C}$; rinse in $\mathrm{dH}_{2} \mathrm{O} ; 10$ min in $1 \%$ bovine serum albumin (BSA) in PBS; rinse in PBS; $5 \mathrm{~min}$ in TdT buffer (Promega)]. The non-fluorescent TUNEL assay included an incubation in $2 \%$ hydrogen peroxide for 15 min to block endogenous peroxidases.

The sections were then incubated in assay buffer containing $6 \mathrm{U}$ of TdT enzyme and 0.3 nmol of labeled nucleotide for $1 \mathrm{~h}$ at $37^{\circ} \mathrm{C}$. The reaction was stopped with $200 \mu \mathrm{l}$ of $0.5 \mathrm{M}$ EDTA followed by two rinses in PBS. The slides were counterstained with Harris' hematoxylin for several seconds, rinsed in tap water, and mounted in glycerol mounting medium (Sigma).
Non-fluorescent digoxygenin-dUTP was detected using a peroxidase labeling method. Slides for this assay were treated for $5 \mathrm{~min}$ in $2 \%$ hydrogen peroxide following proteinase $\mathrm{K}$ treatment and before the TUNEL assay. Following the TUNEL assay these slides were incubated in PBS containing $1 \% \mathrm{BSA}$ and $400 \mathrm{mU} / \mathrm{ml}$ of antidigoxygenin-peroxidase antibody (Boerhinger Mannheim) for $1 \mathrm{~h}$ at $37^{\circ} \mathrm{C}$. The slides were then washed 3 times in PBS. Color was developed using an AEC kit according to the kit instructions, and slides were counterstained with Harris' hematoxylin for several seconds, rinsed in tap water, and mounted in glycerol mounting medium.

TUNEL-positive (apoptotic) cells were counted in a single section with the greatest number of tissues represented and uniformly stained from each embryo. Quantification was done directly on the microscope or using photomicrographs of the sections. Cells were counted in the following tissues: brain, eye, gill, kidney, tail, vasculature, intestine, liver, heart, and mouth. In most cases apoptotic cells were counted in sections from at least 6 embryos, and the average number of TUNEL positive cells per section was calculated. In a few cases, certain tissues were not represented in sections from every embryo, thus decreasing the statistical significance of those results. Results from both the fluorescent and nonfluorescent labeling techniques were combined as there was no difference except for the level of background autofluorescence.

\subsection{Cytochrome P450 assay}

Immunohistochemistry was done according to the methods of Smolowitz et al. (1991) with modifications. In brief, embryo sections were deparaffinized and hydrated in 1\% BSA in PBS. The sections were inserted into Shandon coverplates (Shandon Lipshaw Inc., Pittsburg, PA) and incubated with normal goat serum for 5 min to block nonspecific binding of the secondary antibody. This was followed by two 1-h incubations with $150 \mu 1$ of monoclonal antibody 1-12-3 (Park et al., 1986). The specificity of this antibody for CYP1A has been shown previously (Miller et al., 1989). 
Sections were washed with PBS/BSA after this step and the two following steps. The sections were incubated with secondary antibody (Goat antimouse $\mathrm{IgG}$ ) for $20 \mathrm{~min}$, followed by peroxidase-linked mouse $\mathrm{IgG}$, also for $20 \mathrm{~min}$. After washing with PBS/BSA and then PBS, two 15min incubations (150 $\mu \mathrm{l}$ each) of color developer (Signet; Dedham, MA) were added. Sections were then washed with water, removed from the Shandon covers, and washed twice with water. Sections were next counter stained with Mayer's hematoxylin and mounted in crystalmount. After drying, coverslips were attached with permount. Sections of liver from induced and uninduced scup (Stenotomus chrysops) were run with each batch of embryo sections as a positive and negative control, respectively. When sufficient sections were available, matching sections were stained with a nonspecific IgG (purified mouse myeloma protein, UPC-10) as a negative control. Sections were read blind and scored on two scales, occurrence: 0 (no cells staining) to 3 (all cells staining) and intensity: 0 (no staining) to 5 (very dark red staining). These two scores were multiplied for a final score ('staining index') of $0-15$.

\subsection{Statistics}

Statistical analysis of the apoptosis and CYP1A expression results included analysis of variance (ANOVA) of each treatment compared with controls $(P<0.05)$ using Microsoft EXCEL (Redmond, WA). To determine $\mathrm{LD}_{50}$ and $\mathrm{LC}_{50}$ values, control corrected mortality data was analyzed by probit analysis (PlotIT Software, Haslett, MI) with a $P$ value $<0.05$. The procedure includes a chi-square goodness-of-fit test $(P$ value $>0.05)$ to determine if the probit model fits the data.

\section{Results}

\subsection{Embryotoxicity}

Fundulus embryos exposed to TCDD had a dose-dependent increase in developmental and vascular abnormalities as well as mortality. The observed defects included hemorrhaging, edema, loss of vascular integrity and reduced blood flow, and stunted development. These defects first became apparent 4 days after exposure to TCDD at approximately stage 28 of development and were present in embryos from both exposure regimes. This stage is marked by the development of retinal pigment in the eye, and vascular circulation is well established. By stage 28 most of the organs have formed, and the embryo is undergoing growth and organodifferentiation (Armstrong and Child, 1965).

TCDD caused significant embryo mortality at moderate and high exposures with the $\mathrm{LC}_{50}$ at $19.7 \pm 9.5 \mathrm{pg} / \mu \mathrm{l}$ (water bath exposure) and the $\mathrm{LD}_{50}$ at $0.25 \pm 0.09 \mathrm{ng} / \mathrm{g}$ embryo (nanoinjection; Fig. 1). Most of the embryos that received a dose of TCDD of $20 \mathrm{ng} / \mathrm{g}$ embryo and $500 \mathrm{pg} / \mu \mathrm{l}$ died later in development, near hatching (stages 33$35)$.

\subsection{Apoptosis}

Apoptosis was analyzed in all identifiable tissues; however, many of the embryos did not have all tissues represented even in the best section. Thus, results are shown for the tissues that were consistently seen in most of the embryos, while results in other tissues are discussed.

TCDD caused a dose-dependent increase in the number of apoptotic cells (TUNEL-positive cells) in several tissues of water-bath exposed embryos (Fig. 2). In the early embryos (stage 28-29), only a few tissues were consistently identified (brain, eye, tail, and vascular tissue) for which the numbers of dying cells increased with TCDD exposure (Fig. 2A). The early embryos also had a TCDD dose-dependent increase in TUNEL-positive cells in intestine (data not shown). The control embryos had very few apoptotic cells in each of these tissues.

Mid- and late-stage embryos exposed to TCDD displayed an increase in apoptosis in the brain, eye, gill, kidney, tail, and vasculature relative to controls (Fig. 2B,C). The number of TUNELpositive cells in intestine were approximately eight to 13-fold higher when compared to control (data not shown). In TCDD-treated late-stage embryos there were also higher numbers of apoptotic cells 
in the heart and mouth, but not in liver (data not shown).

Late-stage embryos had apoptotic cell death induced by TCDD treatment in several tissues including eye, brain, gill, and intestine (Fig. 3). Control embryos had some autofluorescence but very few TUNEL-positive cells (Fig. 3A). Conversely, embryos exposed to TCDD had more TUNEL-positive cells that appeared as bright,

A.

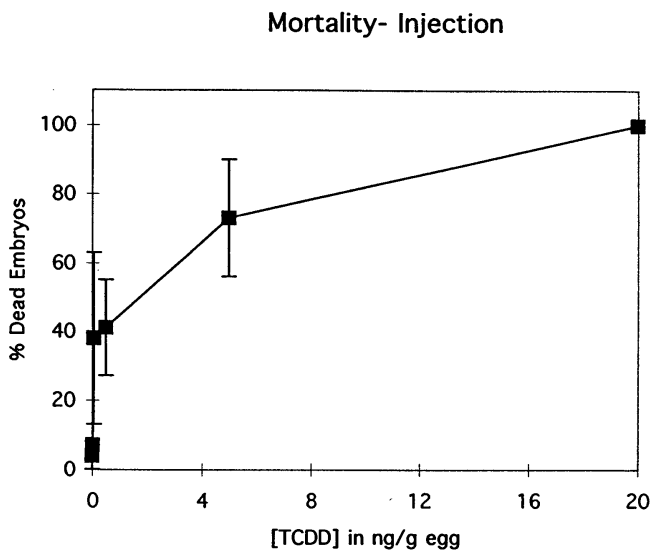

B.

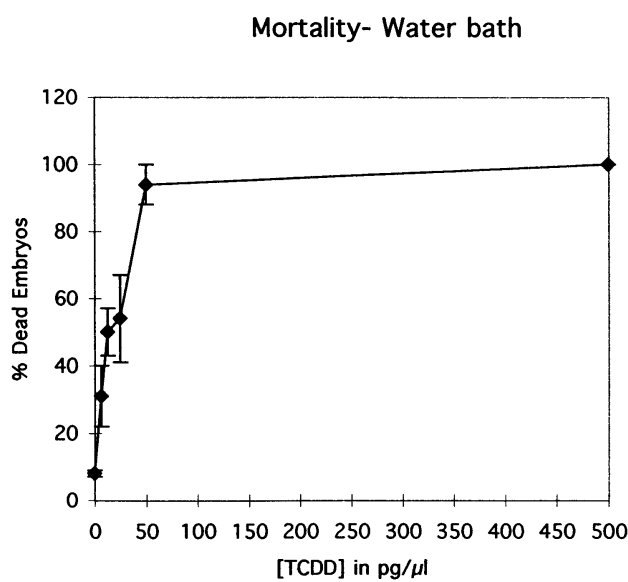

Fig. 1. Mortality of Fundulus embryos exposed to TCDD via microinjection (A) or water bath exposure (B). Embryos were exposed to TCDD during early development and viability was assessed through hatching. The percent of dead embryos (those lacking a heartbeat, pericardial sac, or circulating blood) vs. dose of TCDD are graphed with values representing the average of three experiments for (A) and six experiments for (B). Error bars represent S.E.M.
A.

Early

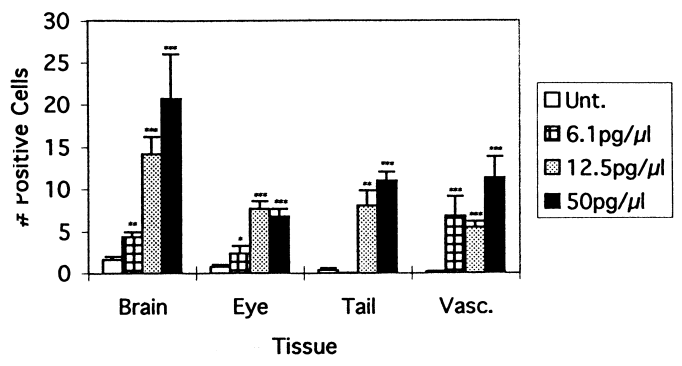

B.

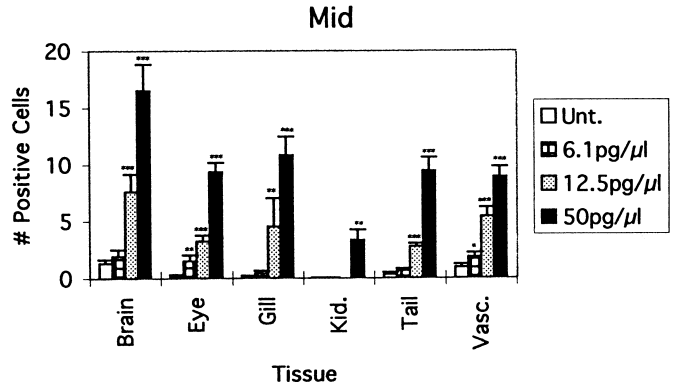

C.

Late

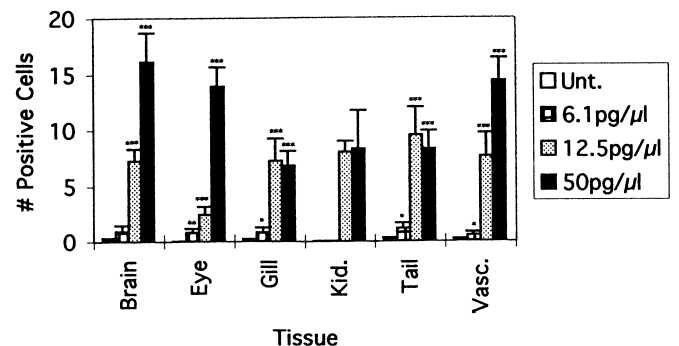

Fig. 2. Graphs of cell death in tissues of Fundulus embryos exposed to TCDD. Embryos were exposed to TCDD for $2 \mathrm{~h}$ in early development and were allowed to develop to three different stages [early (A), mid (B), and late (C)] before analysis of cell death. The bars represent the number of TUNEL-positive cells in several tissues of embryos exposed to increasing concentrations of TCDD (Unt. $=0 \mathrm{pg} / \mu \mathrm{l}$ TCDD; $6.1 \mathrm{pg} / \mu \mathrm{l}$ TCDD, $12.5 \mathrm{pg} / \mu \mathrm{l}$ TCDD, and $50 \mathrm{pg} / \mu \mathrm{l}$ TCDD). Error bars represent S.E.M. ${ }^{* * *} P<0.001,{ }^{* *} P<0.01,{ }^{*} P<$ 0.1 .

punctate spots (Fig. 3B,C). Higher magnification of (B) shows regions of cell death in the brain and gill (Fig. 3D).

\subsection{Cytochrome P4501A expression}

CYP1A expression, as assessed by immunohistochemical staining with monoclonal antibody 1- 
12-3, was induced in Fundulus embryos at all doses of TCDD (Figs. 4 and 5). Early embryos had greatest CYP1A expression in the vasculature of the brain and eye, liver, kidney, and cardiovascular tissue (Fig. 4A). Mid- and latestage embryos also had large increases in CYP1A expression with TCDD exposure in a variety of tissues (Fig. 4B,C). Expression of CYP1A was increased in the vascular endothelium of the brain and eye but not in the surrounding neural or ocular tissue, which is a different pattern than for the TUNEL-positive cells. Increased CYP1A expression was also observed in vasculature of gill, liver, and intestine as well as in epithelial cells of these tissues (Fig. 4 and data not shown). In mid- and late-stage embryos, TCDD also induced CYP1A expression in the vascular endothelium in the heart (data not shown).

The CYP1A staining of control and TCDD-treated, late-stage embryos is illustrated in Fig. 5. Control embryos had no apparent staining for CYP1A (Fig. 5A). All doses of TCDD increased the amount of reddish brown CYP1A staining in a variety of tissues (Fig. 5B-D), and in mid- and late-stage embryos CYP1A expression was maximally induced even at the lowest dose (Figs. 4 and 5). In addition to high CYP1A
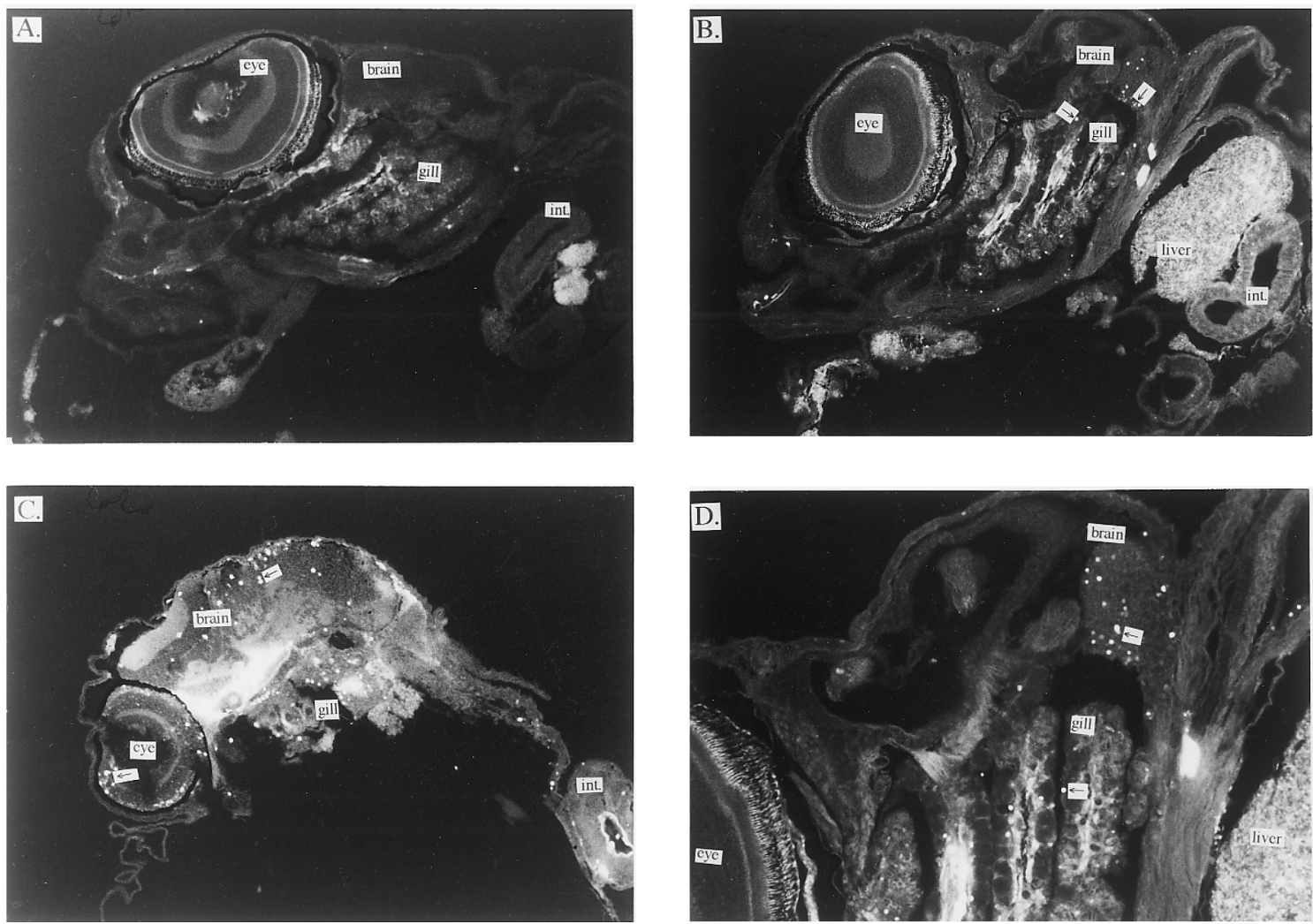

Fig. 3. Photomicrographs of late stage Fundulus embryos after the TUNEL assay. Control embryos (A) show background autoflourescence but very little bright, punctate staining that is apparent in TCDD-exposed embryos (B-D). Embryos exposed to 12.5 (B) and 50 (C) pg/ $\mu 1$ TCDD have an increase in the number of TUNEL-positive cells (arrows) in several tissue including gill, brain, eye and intestine. The photomicrograph in (D) is a higher magnification of (B) showing the bright, punctate and scattered nature of the TUNEL-positive cells. 
A.

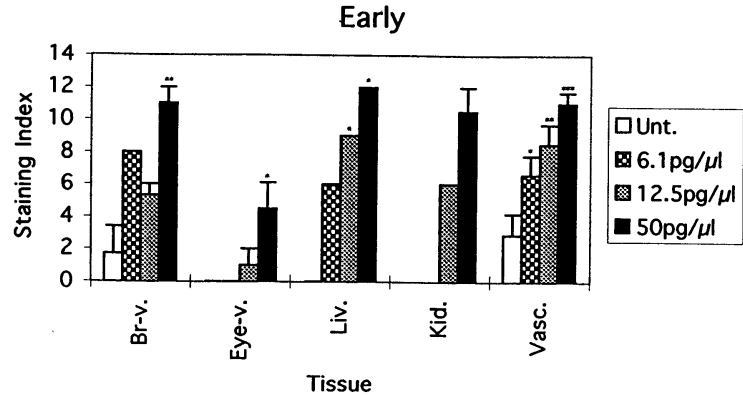

B.

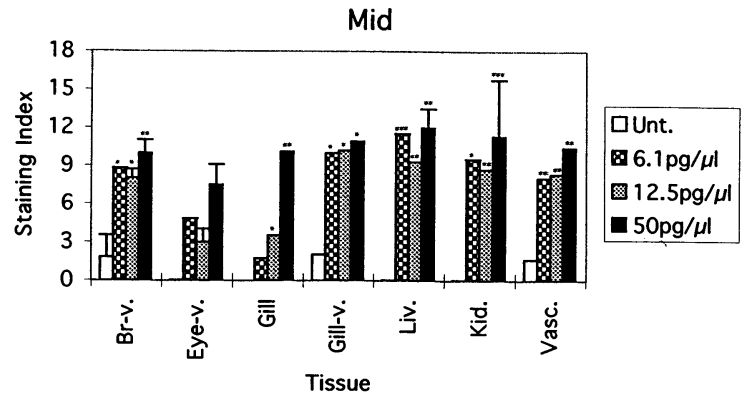

C.

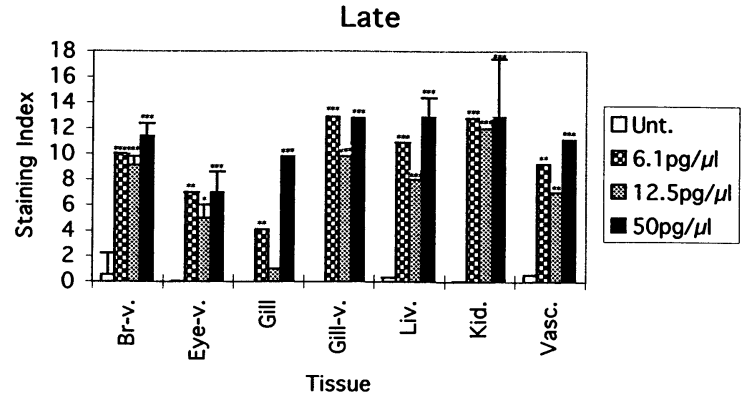

Fig. 4. Graphs of the CYP1A staining index in tissues of Fundulus embryos exposed to TCDD. Embryos were exposed to TCDD for $2 \mathrm{~h}$ in early development and were allowed to develop to three different stages early (A), mid (B), and late (C) before analysis of CYP1A expression. The bars represent the average staining index in several tissues of embryos exposed to increasing concentrations of TCDD (Unt. $=0 \mathrm{pg} / \mu \mathrm{l}$ TCDD; $6.1 \mathrm{pg} / \mu \mathrm{l}$ TCDD, $12.5 \mathrm{pg} / \mu \mathrm{l}$ TCDD, and $50 \mathrm{pg} / \mu 1$ TCDD). Error bars represent S.E.M. ${ }^{* * *} P<0.001,{ }^{* *} P<$ $0.01, * P<0.1$.

expression in the kidney tubules and overall embryonic vasculature, much of the expression in the brain and intestine is in the vascular tissue of those organs, especially at the lower doses (Fig. $5 \mathrm{~B}, \mathrm{C}$; note the elongated staining pattern).

\section{Discussion}

TCDD is a potent developmental toxicant and causes vascular problems in a variety of fish embryos (Peterson, et al., 1993). Fundulus embryos exposed to TCDD had defects similar to other fish embryos (Walker et al., 1991; Cantrell et al. 1996, 1998; Guiney et al., 1997; Hornung et al., 1999) including hemorrhaging, edema, loss of blood flow, and stunted development. Our injection data of the toxicity of TCDD indicates that Fundulus embryos ( $\mathrm{LD}_{50} \approx 250 \mathrm{pg} / \mathrm{g}$ embryo) were more sensitive than medaka embryos $\left(\mathrm{LC}_{50 \mathrm{egg}} \approx\right.$ $1250 \mathrm{pg} / \mathrm{g}$ egg) and zebrafish embryos $\left(\mathrm{LC}_{50 \mathrm{egg}} \approx\right.$ $2500 \mathrm{pg} / \mathrm{g} \mathrm{egg}$ ) and less sensitive than lake trout embryos $\left(\mathrm{LC}_{50 \mathrm{egg}} \approx 50-100 \mathrm{pg} / \mathrm{g}\right.$ egg) (Elonen et al., 1998). The $\mathrm{LD}_{50}$ value we observed in Fundulus is lower than expected considering the similar relative sensitivities of medaka and Fundulus to other compounds and other mechanisms. However, a range of $\mathrm{LD}_{50}$ values for TCDD can exist within a species, dependent on exposure conditions or strain of fish (Walker et al., 1991; Wright et al., 1996). It is also interesting to note that certain populations of Fundulus can develop resistance to TCDD in the environment (Prince and Cooper, 1995; Elskus et al., 1999; Hahn, 1998). Thus, both physiological and genetic factors can influence the relative sensitivity of a particular strain (or population) of fish within a species.

TCDD-induced apoptosis in Fundulus embryos is consistent with the tissue-specific patterns observed in medaka embryos (Cantrell et al., 1996, 1998). Vascular tissue in early stage embryos was a sensitive target of TCDD, but many other tissues also had increased cell death suggesting that vascular tissue was not the only target of TCDDinduced apoptosis in Fundulus embryos. The previous studies with medaka embryos identified cell death in the medial yolk vein as the primary target site of TCDD exposure in early embryos. We were unable to locate this vessel consistently in sections of Fundulus embryos, possibly due to the extensive nature of the vasculature or disruption of the yolk and surrounding vessels during embryo processing. The similar tissue-specific patterns of apoptosis seen in medaka and Fundulus do, however, suggest a similar response to TCDD exposure in these fish species. 
Other tissues in which apoptosis was increased by TCDD exposure included brain, eye, gill, kidney, tail, and intestine. In most cases it was not possible to identify apoptosis specifically in the vascular tissue of these organs (e.g. if a vessel was viewed in cross section, it might look like a single TUNEL-positive cell). In some of these nonvascular tissues, the increase in cell death may have resulted from the deterioration of the blood vessels supplying that tissue. That is, cell death in some tissues, such as neuronal tissue, may be secondary to the primary insults caused by TCDD. This hypothesis is consistent with the observation in medaka that cell death in neural tissues had a different slope of the dose-response curve as compared with mortality (Cantrell et al., 1998). The timing of embryo collection for the apoptosis assay is also likely to be an important factor in detecting vascular cell death. Apoptosis is a rapid process in which the celluar products do not remain. Therefore, one must catch the cells in the dying process to detect them.

There was an increase in CYP1A expression in Fundulus embryos exposed to TCDD in addition to an increase in apoptotic cells. It appears that CYP1A expression is a more sensitive response than apoptosis. However, CYP1A expression is prolonged whereas cell death occurs quickly, and the window in which the latter can be detected by the TUNEL assay is narrow. Thus, the differences
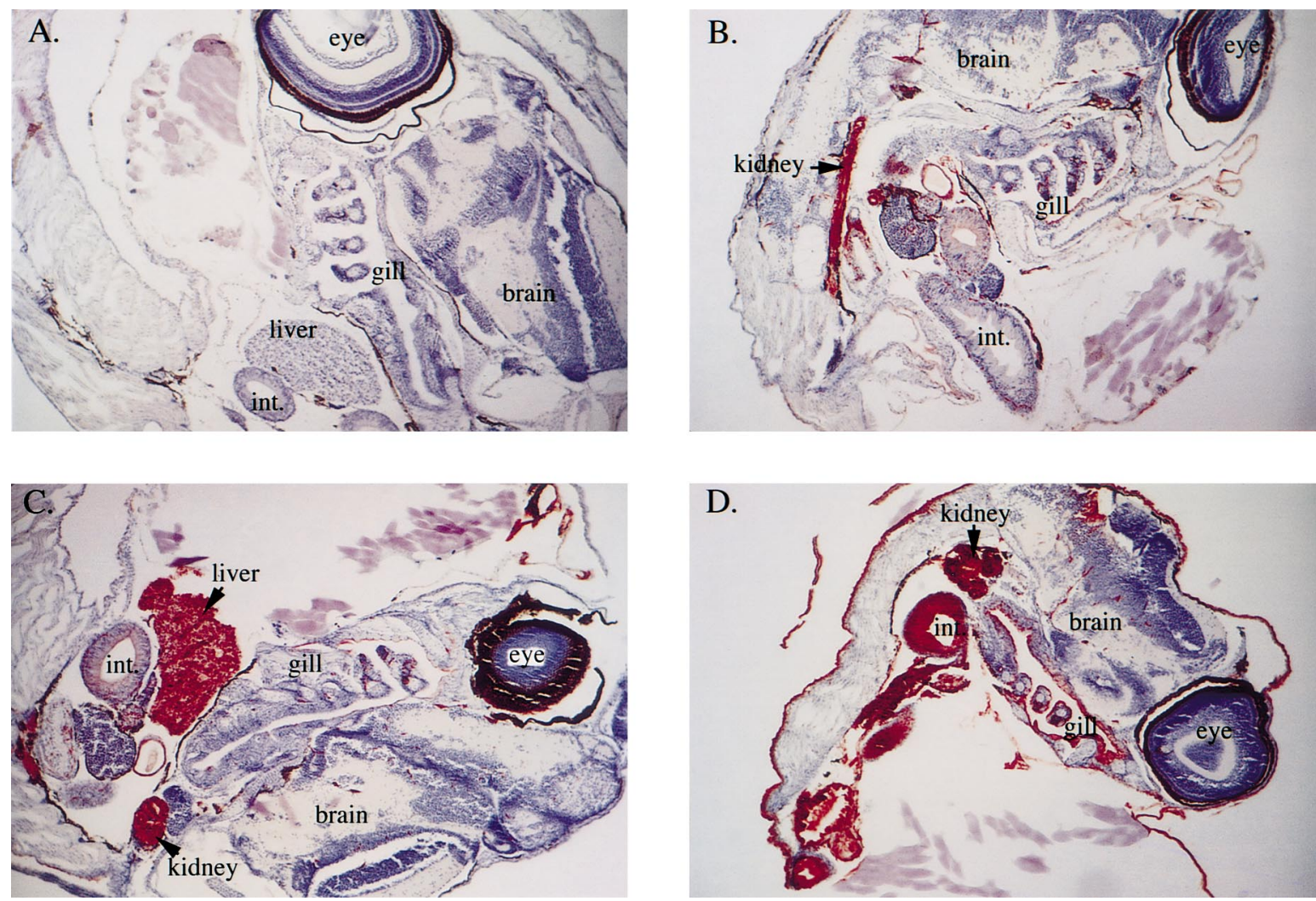

Fig. 5. Photomicrographs of Late stage Fundulus embryos after immunostaining for CYP1A. The control embryo (A) has no reddish brown CYP1A labeling. Embryos exposed to $6.1 \mathrm{pg} / \mu 1 \mathrm{TCDD}$ (B) have increased CYP1A staining in the kidney and vascular cells in the gill and intestine. The embryo exposed to $12.5 \mathrm{pg} / \mu \mathrm{l}$ TCDD also has a large increase in staining in the liver and vasculature, and the embryo exposed to $50 \mathrm{pg} / \mu \mathrm{l}$ TCDD has very dark CYP1A staining in the embryonic vasculature, kidney, liver, intestine and gill. 
we observed may be due to timing. There was co-occurrence of TCDD-induced cell death and CYP1A expression in some tissues and cell types (vasculature, gill, intestine). However, in other tissues (brain, eye, liver), CYP1A expression and cell death did not co-occur in the same cell type. A primary site for TCDD-induced CYP1A expression was the vascular tissue throughout the embryo. Therefore, apoptosis of epithelial cells in some tissues (brain, eye) could be a consequence of cell death in the vasculature of that tissue, as mentioned earlier. Alternatively, TCDD may induce apoptotic cell death and CYP1A expression through unrelated mechanisms in some tissues. TCDD induced a high level of CYP1A expression in the liver, as expected, although there was little or no increase in cell death observed in this organ. Again, this is consistent with observations seen in medaka (Cantrell et al., 1996, 1998) and suggests that the liver is not as susceptible to apoptosis as compared to other tissues.

Another interesting observation is that in our study the control embryos had no CYP1A expression in the kidney. Fundulus larvae and adults from other populations have a low basal level of CYP1A expression in proximal tubules of the kidney even in the control fish (Elskus et al., 1999; Bello et al., 2000). CYP1A is only active at low basal levels during the embryonic stages (Binder and Stegeman, 1984) and may not be detected using immunohistochemical techniques. Alternatively, the embryos used in this study could be from a less contaminated location than the other studies.

The toxicity of TCDD to Fundulus embryos in this study is similar to that seen in other fish embryos (e.g. vascular lesions) so it is somewhat surprising that, in terms of cell death, the vascular system does not stand out as the primary target site for TCDD. We may get a more complete picture of cell death in vascular and other tissues by choosing more than three embryonic stages for the TUNEL assay. Also, we did not focus on the medial yolk vein in the embryos, which may be a primary target of TCDD-induced cell death since it is an initial site of exposure as the embryo utilizes the yolk. However,
Fundulus is more sensitive to TCDD than medaka, and we may be seeing more of the sublethal and secondary effects of TCDD exposure along with cell death in the vasculature in these embryos. Cantrell et al. (1998) found that medaka embryos exposed to sublethal doses of TCDD had increased cell death and CYP1A expression in gill and intestine while embryos exposed to lethal doses had more pronounced effects on the vasculature. This suggests a different pattern in the embryos exposed to low doses of TCDD.

Thus we have shown that Fundulus embryos exhibit responses to TCDD exposure that is consistent with the responses observed in other fish embryos and that indicate a role for TCDD in inducing CYP1A expression and cell death in a variety of tissues. However, it is not clear that CYP1A induction is a contributing factor in the increased apoptosis in all cell types. CYP1A plays a role in increasing oxidative stress in cells (presumably leading to increased cell death), but if the cells are protected (e.g. liver cells), they may not die in response to CYP1A induction. Perhaps repeating the assays on embryos at more developmental stages will clarify this. It will also be interesting to examine the responses to TCDD of embryos of Fundulus from resistant populations. These fish may have adaptations that alter the patterns of TCDD-induced cell death and CYP1A expression.

\section{Acknowledgements}

We would like to thank Sue Kelly, Elizabeth Maclean, Steven Ploch, and George Monteverdi for helpful discussions and Diana Papoulias and Jeff Whyte for critical reviews. This work was supported by grants from the Duke University Marine/Freshwater Biomedical Center, NIEHS training grant no. ES07031, and the Exxon Corporation. Partial support was also obtained from the Superfund Basic Research Program (NIEHS grant P42 ES07381 to MEH). Contribution no. 10160 from the Woods Hole Oceanographic Institution. 


\section{References}

Armstrong, P.B., Child, J.S., 1965. Stages in the normal development of Fundulus heteroclitus. Biol. Bull. 128, 143169.

Bello, S.M., Franks, D.G., Stegeman, J.J., Hahn, M.E., 2000. Acquired resistance to aryl hydrocarbon receptor agonists in a population of Fundulus heteroclitus from a marine superfund site: in vivo and in vitro studies on the induction of xenobiotic metabolizing enzymes. Submitted for publication.

Binder, R.L., Stegeman, J.J., 1980. Induction of aryl hydrocarbon hydroxylase activity in embryos of an estuarine fish. Biochem. Pharmacol. 29, 949-951.

Binder, R.L., Stegeman, J.J., 1984. Microsomal electron transport and xenobiotic monooxygenase activities during the embryonic period of development in the killifish, Fundulus heteroclitus. Toxicol. Appl. Pharmacol. 73, 432-443.

Binder, R.L., Stegeman, J.J., Lech, J.J., 1985. Induction of cytochrome P-450-dependent monooxyenase systems in embryos and eleutheroembryos of the killifish Fundulus heteroclitus. Chem. Biol. Interact. 55, 185-202.

Birnbaum, L.S., 1994. The mechanism of dioxin toxicity: relationship to risk assessment. Environ. Health Perspect. 102 (Suppl. 9), 157-167.

Cantrell, S.M., Lutz, L.H., Tillitt, D.E., Hannink, M., 1996. Embryotoxicity of 2,3,7,8-tetrachlorodibenzo- $p$-dioxin (TCDD): the embryonic vasculature is a physiological target for TCDD-induced DNA damage and apoptotic cell death in medaka (Orizias latipes). Toxicol. Appl. Pharmacol. 141, 23-34.

Cantrell, S.M., Joy-Schlezinger, J., Stegeman, J.J., Tillitt, D.E., Hannink, M., 1998. Correlation of 2,3,7,8-tetrachlorodibenzo-p-dioxin-induced apoptotic cell death in the embryonic vasculature with embryotoxicity. Toxicol. Appl. Pharmacol. 148, 24-34.

Detrich, H.W., Westerfield, M., Zon, L.I., 1999. Overview of the zebrafish system. Methods Cell Biol. 59, 3-10.

Elonen, G.E., Spehar, R.L., Holcombe, G.W., Johnson, R.D., Fernandez, J.D., Erickson, R.J., Tietge, J.E., Cook, P.M., 1998. Comparative toxicity of 2,3,7,8-tetrachlorodibenzo$p$-dioxin to seven freshwater fish species during early lifestage development. Environ. Toxicol. Chem. 17, 472-483.

Elskus, A.A., Monosson, E., McElroy, A.E., Stegeman, J.J., Woltering, D.S., 1999. Altered CYP1A expression in Fundulus heteroclitus adults and larvae: a sign of pollutant resistance? Aquat. Toxicol. 45, 99-113.

Gavrieli, Y., Sherman, Y., Ben-Sasson, S.A., 1992. Identification of programmed cell death in situ via specific labeling of nuclear DNA fragmentation. J. Cell Biol. 119, 493-501.

Guiney, P.D., Smolowitz, R.M., Peterson, R.E., Stegeman, J.J., 1997. Correlation of 2,3,7,8-tetrachlorodibenzo- $p$ dioxin induction of cytochrome P4501A in vascular endothelium with toxicity in early life stages of lake trout. Toxicol. Appl. Pharmacol. 143, 256-273.

Hahn, M.E., 1998. Mechanisms of innate and acquired resistance to dioxin-like compounds. Rev. Toxicol. Ser. B Environ. Toxicol. 2, 395-443.
Heimler, I., Trewin, A.L., Chaffin, C.L., Rawlins, R.G., Hutz, R.J., 1998. Modulation of ovarian follicle maturation and effects on apoptotic cell death in holtzman rats exposed to 2,3,7,8-tetrachlorodibenzo- $p$-dioxin (TCDD) in utero and lactationally. Reprod. Toxicol. 12, 69-73.

Henry, T.R., Spitsbergen, J.M., Hornung, M.W., Abnet, C.C., Peterson, R.E., 1997. Early life stage toxicity of 2,3,7,8-tetrachlorodibenzo- $p$-dioxin in Zebrafish (Danio rerio). Toxicol. Appl. Pharmacol. 142, 56-68.

Henshel, D., 1998. Developmental neurotoxic effects of dioxin and dioxin-like compounds on domestic and wild avian species. Environ. Toxicol. Chem. 17, 88-98.

Hornung, M.W., Spitzbergen, J.M., Peterson, R.E., 1999. 2,3,7,8-Tetrachlorodibenzo- $p$-dioxin alters cardiovascular and craniofacial development and function in sac fry of rainbow trout (Oncorhynchus mykiss). Toxicol. Sci. 47, $40-51$.

Kurl, R.N., Abraham, M., Olnes, M.J., 1993. Early effects of 2,3,7,8-tetrachlorodibenzo- $p$-dioxin (TCDD) on rat thymocytes in vitro. Toxicology 77, 103-114.

MacLusky, N.J., Brown, T.J., Schantz, S., Seo, B.W., Peterson, R.E., 1998. Hormonal interactions in the effects of halogenated aromatic hydrocarbons on the developing brain. Toxicol. Ind. Health 14, 185-208.

Miller, M.R., Hinton, D.R., Buhler, D.R., 1989. Cytochrome $\mathrm{P}-450 \mathrm{E}$ induction and localization in gill pillar (endothelial) cells of scup and rainbow trout. Aquat. Toxicol. 14, 307-322.

Mimura, J., Yamashita, K., Nakamura, K., Morita, M., Takagi, T.N., Nakao, K., Ema, M., Sogawa, K., Yasuda, M., Katsuki, M., Fujii-Kuriyama, Y., 1997. Loss of teratogenic response to 2,3,7,8-tetrachlorodibenzo- $p$-dioxin (TCDD) in mice lacking the $\mathrm{Ah}$ (dioxin) receptor. Genes Cells 2, 645-654.

Morrison, H.G., Weil, E.J., Karchner, S.I., Sogin, M.L., Stegeman, J.J., 1998. Molecular cloning of CYP1A from the estuarine fish Fundulus heteroclitus and phylogenetic analysis of CYP1A genes: update with new sequences. Comp. Biochem. Physiol. 121C, 231-240.

Nebert, D.W., Peterson, D.D., Fornace, A.J., 1990. Cellular response to oxidative stress: the $[\mathrm{Ah}]$ gene battery as a paradigm. Environ. Health Perspect. 88, 13-25.

Nebert, D.W., Roe, A.L., Dieter, M.Z., Solis, W.A., Yang, Y., Dalton, T.D., 2000. Role of the aromatic hydrocarbon receptor and $[\mathrm{Ah}]$ gene battery in the oxidative stress response, cell cycle control, and apoptosis. Biochem. Pharmacol. 59, 65-85.

Park, S.S., Miller, J., Klotz, A.V., Kloepper-Sams, P.J., Stegeman, J.J., Gelboin, H.V., 1986. Monoclonal antibodies to liver microsomal cytochrome P-450E of the marine fish Stenotomus chrysops (scup): cross-reactivity with 3-methylcholanthrene induced rat cytochrome P-450. Arch. Biochem. Biophys. 249, 339-350.

Peters, J.M., Narotsky, M.G., Elizondo, G., Fernandez-Salguero, P.M., Gonzalez, F.J., Abbott, B.D., 1999. Amelioration of TCDD-induced teratogenesis in aryl hydrocarbon receptor (AhR)-null mice. Toxicol. Sci. 47, 86-92. 
Peterson, R.E., Theobald, H.M., Kimmel, G.L., 1993. Developmental and reproductive toxicity of dioxins and related compounds: cross species comparisons. Crit. Rev. Toxicol. 23, 283-335.

Piqueras, B., Autran, B., Debre, P., Gorochov, G., 1996. Detection of apoptosis at the single-cell level by direct incorporation of fluorescein-dUTP in DNA strand breaks. BioTechniques 20, 634-640.

Powers, D.A., Schulte, P.M., 1998. Evolutionary adaptations of gene structure and expression in natural populations in relation to a changing environment: a multidisciplinary approach to address the million-year saga of a small fish. J. Exp. Zool. 282, 71-94.

Prince, R., Cooper, K.R., 1995. Comparisons of the effects of $2,3,7,8$-tetrachlorodibenzo- $p$-dioxin on chemically impacted and nonimpacted subpopulations of Fundulus heteroclitus: II. Metabolic considerations. Environ. Toxicol. Chem. 14, 589-595.

Sakamoto, M.K., Mima, S., Tanimura, T., 1995. A morphological study of liver lesions in Xenopus larvae exposed to 2,3,7,8-tetrachlorodibenzo- $p$-dioxin (TCDD) with special reference to apoptosis of hepatocytes. J. Environ. Pathol. Toxicol. Oncol. 14, 69-82.

Selman, K., Wallace, R.A., 1986. Gametogenesis in Fundulus heteroclitus. Am. Zool. 26, 173-192.

Smolowitz, R.M., Hahn, M.E., Stegeman, J.J., 1991. Immunohistochemical localization of cytochrome P4501A1 induced by $3,3^{\prime}, 4,4^{\prime}$-tetrachlorobiphenyl and by 2,3,7,8-tetrachlorodibenzofuran in liver and extrahepatic tissues of the teleost Stenotomus chrysops (scup). Drug. Metab. Dispos. 19, 113-123.

Spitsbergen, J.M., Walker, M.K., Olson, J.R., Peterson, R.E., 1991. Pathological lesions in the early life stages of lake trout (Salvelinus namaycush) exposed to 2,3,7,8-tetrachlorodibenzo- $p$-dioxin as fertilized eggs. Aquat. Toxicol.
$19,41-72$.

Stegeman, J.J., Hahn, M.E., 1994. Biochemistry and molecular biology of monooxygenases: current perspectives on forms, functions, and regulation of cytochrome P450 in aquatic species. In: Malins, D.C., Ostrander, G.K. (Eds.), Aquatic Toxicology: Molecular, Biochemical, and Cellular Perspectives. Lewis Publishers, Boca Raton, FL, pp. 87-206.

Walker, M.K., Spitsbergen, J.M., Olson, J.R., Peterson, R.E., 1991. 2,3,7,8-Tetrachlorodibenzo- $p$-dioxin (TCDD) toxicity during early life stage development of lake trout (Salvelinus namycush). Can. J. Fish. Aquat. Sci. 48, 875883.

Walker, M.K., Zabel, E.W., Akerman, G., Balk, L., Wright, P.J., Tillitt, D.E., 1996. Fish egg injection as an exposure route for early life stage toxicity studies. Description of two unique methods. In: Ostrander, G. (Ed.), Techniques in Aquatic Toxicology. CRC Press/Lewis Publishers, Boca Raton, FL, pp. 41-72.

Whitlock, J.P., Chichester, C.H., Bedgood, R.M., Okino, S.T., Ko, H.P., Ma, Q., Dong, L., Li, H., Clarke-Katzenberg, R., 1997. Induction of drug-metabolizing enzymes by dioxin. Drug Metab. Rev. 29, 1107-1127.

Wilson, P.J., Tillitt, D.E., 1996. Rainbow trout embryotoxicity of a complex contaminant mixture extracted from Lake Michigan lake trout. Mar. Environ. Res. 42, 129-134.

Wright, P.J., Papoulias, D.M., Tillitt, D.E., 1996. A comparison of the TCDD $\mathrm{LD}_{50}$ for medaka embryos using different exposure protocols. 17th Annual Meeting of the Society of Environmental Toxicology and Chemistry, Washington, DC, 17-21 November.

Yao, Y., Hoffer, A., Chang, C., Puga, A., 1995. Dioxin activates HIV-1 gene expression by an oxidative stress pathway requiring a functional cytochrome P450 CYP1A1 enzyme. Environ. Health Perspect. 103, 366-371. 